УДК 94(73) - 054.73 (=411.16)]«1944/1945»

DOI: $10.24919 / 2519-058 x .9 .150367$

\author{
Ірина РАДЧЕНКО, \\ orcid.org/0000-0003-4522-1344 \\ аспірантка кафедри всесвітньої історії \\ Дніпровського національного університету імені Олеся Гончара, \\ науковий співробітник Українського інституту вивчення Голокосту «Ткума» \\ (Україна, Дніпро) irisha_89@ukr.net
}

\title{
ДІЯЛЬНІСТЬ АМЕРИКАНСЬКОЇ УРЯДОВОЇ КОМІСІЇ 3 ПИТАНЬ ВІЙСЬКОВИХ БІЖЕНЦІВ: ЄВРЕЙСЬКИЙ АСПЕКТ (1944 - 1945)
}

\begin{abstract}
Мета дослідження - характеристика діяльності Комісії з питань військових біженців щчодо надання порятунку єврейському населенню у краӥнах Європи протягом 1944-1945 рр. Методологія дослідження спирається на принципах історизму, системності, науковості, а також на використання загальнонаукових методів (аналізу і синтезу, індукиії та дедукиіï) та спеціально-історичних (методи історіографічного та джерелознавчого аналізу, історико-системний, історико-генетичний). Наукова новизна полягає у тому, що вперше у вітчизняній історіографіï на основі виключно зарубіжних архівних матеріалів з 'ясована роль Комісії з питань військових біженців у прочесі допомоги та порятунку євреїв Свропи, охарактеризовані основні напрямки діяльності иієї установи на останньому етапі Другої світової війни. Висновки. Комісія з питань військових біженців (WRB) була першою урядовою агениією, яка надавала допомогу та порятунок єврейському населенню в роки Голокосту. Вона була створена указом Президента Ф. Д. Рузвельта у 1944 р. у відповідь на масові запити американських єврейських товариств щодо надання допомоги та порятунку їх європейських братів. WRB вдалося наладити ефективну взасмодію з різними установами (JDC, ICRC, WJC, JA, «Vaad Haatzala») по всьому світу. Основними видами діяльності WRB були: 1) видача спеціальних лічензій на гуманітарну діяльність інших установ; 2) передача коштів посередникам для здійснення допомоги та порятунку; 3) надання харчів, одягу, медикаментів постраждалим особам; 4) видача віз для подальшого виїзду за кордон; 5) організачія еміграиії. Завдяки иии видам діяльності, WRB вдалося врятувати десятки тисяч иивільних осіб (переважно євреїв) у європейських країнах. Проте, враховуючи, щуо WRB розпочала свою роботу лише у 1944 р., коли переважна частина єврейського населення у Європі була знищена, можемо припустити, щуо рятувальні дії Комісії могли бути більш продуктивними, якщо б вона функиіонувала на початку Другої світової війни. Із закінченням війни у Європі у 1945 р., в діяльності WRB більше не було потреби, та вона була скасована у вересні 1945 p.
\end{abstract}

Ключові слова: Комісія з питань військових біженців, США, єврейські біжениі, міжнародні організаиії, Голокост.

Iryna RADCHENKO, Graduate student, World History Department at Oles Honchar Dnipro National University, Research associate at «Tkuma» Ukrainian Institute for Holocaust Studies (Ukraine,Dnipro),irisha_89@ukr.net

\section{ACTIVITIES OF THE USA GOVERNMENTAL WAR REFUGEE BOARD: JEWISH ASPECT (1944 - 1945)}

The purpose of the study - to describe the War Refugee Board's activities concerning the providing of salvation to the Jewish population in European countries during 1944-1945. The methodology of the study is based on the principles of historicism, consistency, science, as well as on the use of general 
scientific methods (analysis and synthesis, induction and deduction) and special-historical (historiographical and source-analysis analysis, historical-systemic, historical-genetic methods). The novelty is that, firstly, in the national historiography on the basis of exclusively foreign archival materials, the role of the WRB in the process of assistance and rescue of European Jews is clarified; main directions of this institution 's activity in the last stage of the World War II are described. Conclusions. The WRB was the first government agency for helping and rescuing the Jews during the Holocaust. The organization was established by Executive Order by President F. D. Roosevelt in 1944, as response on mass requests of American Jewish societies to provide aid and rescue their European brethren. The WRB managed to establish effective interaction with various institutions (the JDC, ICRC, WJC, JA, "Vaad Haatzala») around the world. The main activities of the WRB were: 1) the issuance of special licenses for the humanitarian activities of other institutions; 2) transfer the funds to intermediaries for assistance and rescue; 3) provision of food, clothing, medicines to victims; 4) issuing visas for further travel abroad; 5) organization of emigration. Through these kinds of activities, the Board managed to save tens of thousands of civilian persons (mostly Jews) in European countries. But, considering the fact, that the WRB began its work only in 1944, when the main part of Jewish population in Europe was exterminated, we can assume that the rescue activities of the agency could be more productive, if it functioned from the beginning of the World War II. With the end of war in Europe in 1945, the activity of the WRB was no longer needed, and the organization was dissolved in September 1945.

Key words: War Refugee Board, USA, Jewish refugees, international organizations, Holocaust.

Постановка проблеми. Значна кількість єврейського населення континенту Свропи була знищена нацистською Німеччиною та її союзниками, проте тисячі врятованих євреїв з різних країн є доказом діяльності різних міжнародних організацій, однією 3 яких стала Комісія з питань військових біженців - War Refugee Board (далі - WRB), створена урядом США у 1944 p.

Сучасні фахівці з історії Голокосту продовжують робити акцент на дослідженнях саме процесу знищення єврейського населення. Порятунок, наданий різними міжнародними установами, особливо не приймається до уваги через диспропорцію між кількістю загиблих та кількістю врятованих євреїв Європи. Тим не менш, це питання $\epsilon$ вкрай важливим у вивченні історії Голокосту, адже торкається такого значущого аспекту Голокосту як виживання через порятунок.

Аналіз досліджень. Питання створення Комісії з питань військових біженців вивчалося переважно західними дослідникам. У зарубіжній історіографії найбільш виразно це питання висвітлено у роботах Р. Ербельдінг (Erbelding, 2018), М. Пенковера (Penkower, 1988). Ці автори багато уваги приділяють саме дипломатичним перемовинам напередодні утворення цієї установи (дискусіям між урядовцями США, міжнародними єврейськими агенціями, ін.), оскільки, як і кожна урядова інституція, Комісію було створено після цілої низки кулуарних перемовин і домовленостей між високопосадовцями США. Проте, автори доволі побіжно говорять про ті операції, які WRB здійснив самостійно чи взаємодіючи з іншими установами.

Окремо відзначимо роботу ізраїльського дослідника Є. Бауера (Bauer, 1987), присвячену діяльності відомої міжнародної установи - JDC ${ }^{1}$, яка тісно співпрацювала 3 WRB під час проведення певних операцій. Діяльність WRB представлена неповно і лише у взаємодії з єврейським комітетом. Дослідниця Д. Офер (Ofer, 1990) підіймає питання допомоги Єврейської агенції у здійсненні єврейської еміграції до Палестини впродовж війни. Зазначимо, що авторка достатньо детально говорить про ту чи іншу операцію з надання допомоги чи порятунку, проте роль WRB применшена - мож-

${ }^{1}$ Американський єврейський об’єднаний розподільчий комітет (англ. American Jewish Joint Distribution Committee, JDC) - благодійна єврейська організація, створена у 1914 р. 3 метою допомоги євреям у всьому світі. 
ливо, через «пізню» активізацію урядової організації у процес допомоги - лише 3 $1944 \mathrm{p}$.

Певну інформацію щодо утворення WRB містить низка робіт, присвячених темі Голокосту в цілому. Так, наприклад, Л. Лондон (London, 2003), В. Рубінштейн (Rubinstein, 1997), Д. Вайман (Wyman, 2007) говорять про зовнішню політику британського та американського урядів, торкаючись саме реакції як на події Голокосту, так i, власне, створення Комісії як наслідок тих реакцій у західному суспільстві. Робота Д. Горного (Gorny, 2012), присвячена відображенню подій Голокосту в єврейській пресі тих років, показує, зокрема, тривалий процес обговорення урядовцями США створення агенції 3 порятунку.

Зауважимо, що жодної роботи, присвяченої Комісії або іншій міжнародній інституції із порятунку євреїв Свропи в роки Голокосту у вітчизняній історіографії немає. Отже, розкриття цього питання шляхом залучення матеріалів із зарубіжних архівів $€$ нагальним у сучасній історичній науці.

Для дослідження були використані документи з бібліотек Ф. Рузвельта, Г. Трумена, які містять спеціальні колекції про створення та діяльність WRB у 1944 - 1945 pp., функціонування інших установ, які співпрацювали з Комісією (JDC, $\mathrm{ICRC}^{2}, \mathrm{WJC}^{3}, \mathrm{JA}^{4}$ тощо). Це, переважно, офіційні документи - звіти, службові телеграми, меморандуми. Зважаючи на характер створення, діяльності WRB як урядової агенції, повністю підзвітної президенту США, залучення саме офіційної документації дозволяє створити уявлення про поточну діяльність агенції, основні рятувальні операції, проблеми, які поставали перед нею на певному етапі тощо.

Мета статті полягає у характеристиці діяльності Комісії з питань військових біженців з надання порятунку єврейському населенню у країнах Європи протягом 1944 1945 pp.

Виклад основного матеріалу. Отже, WRB була створена у 1944 р., але історія іï створення бере свій початок ще у 1942 р. На той момент масове знищення єврейського населення у СРСР вже майже були завершено, натомість в інших країнах Свропи «остаточне вирішення єврейського питання» вже було розпочато. Лише 31942 р. уряди західних країн через дипломатичні канали стали отримувати звістки про знищення єврейського населення Європи. Це, зокрема, підтверджують численні документи (звіти WJC, нота польського уряду у вигнанні до західних держав із даними про масове знищення євреїв). Так, 17 грудня 1942 р. спільна декларація союзників (Об’єднаних націй), зроблена одночасно у Лондоні, Вашингтоні та Москві офіційно підтвердила, що нацисти здійснюють систематичні масові вбивства єврейських цивільних осіб, згідно політики знищення європейського єврейства (London, 2003: 203.)

Зауважимо, що до цього часу допомога євреям надходила від різних міжнародних агенцій, зокрема JDC, ICRC, WJC, $\mathrm{OSE}^{5}$ (у Франції), $\mathrm{AFSC}^{6}$ тощо. Але це була

\footnotetext{
${ }^{2}$ Міжнародний Комітет Червоного Хреста (International Committee of the Red Cross, ICRC) - найстаріша міжнародна гуманітарна організація з надання допомоги «усім постраждалим, незалежно від етнічної, релігійної приналежності».

${ }^{3}$ Всесвітній Єврейський Конгрес (World Jewish Congress, WJC) - єврейська сіоністська політична організація, яка в роки Голокосту активно надавала порятунок та сприяла єврейській еміграції до Палестини.

4 Єврейська агенція (Jewish Agency, JA) - єврейська установа, створення для сприяння еміграції усіх євреїв до Палестини.

${ }_{5}^{5}$ Товариство допомоги дітям (Euvre de Secours aux Enfants, OSE) - французька єврейська гуманітарна організація.

${ }^{6}$ Американський комітет Друзів на службі суспільству (American Friends Service Committee, AFSC) - opганізація, афілійована з Релігійними товариством Друзів (Квакерів), яка працює на захисті миру та соціальної справедливості у США та світі.
} 
фрагментарна допомога, яка істотно не могла поліпшити стан цивільного населення, яке потерпало від страждань. До того ж, це були ініціативи приватних кіл (донорів, переважно заможне американське єврейство, яке надавало різні кошти на порятунок європейського єврейства); уряди західних країн, як правило, не брали в них участь.

Перші суттєві спроби донести інформацію західному суспільству (i, передусім, урядам цих країн) про ті події, що відбувалися у Європі, датуються початком 1943 р. 21 січня 1943 р. посол США у Швейцарії Леланд Гаррісон направив телеграму № 482 для президента Американського Єврейського Конгресу Стівена Вайса з передачею до Державного секретаря США Самнера Веллеса, в якій Герхард Рігнер, секретар WJC у Швейцарії, звітував про «6 тис. євреїв, яких щодня вбивають в одному польському місті; євреї Берліна вже на порозі власного кінця; зі 136 тис. євреїв, депортованих до «Трансністрії», 60 тис. вже померло» ${ }^{7}$. Веллес передав цю телеграму С. Вайсу, і Американський Єврейський конгрес вже готував масовий мітинг за негайний порятунок західними союзниками євреїв Свропи на «Медісон-сквер-гарден» у Нью-Йорку, що відбувся 1 березня 1943 р. та зібрав близько 70 тис. осіб (єврейського та неєврейського населення) (Penkower, 1988: 127.).

Після цих подій активізувалася діяльність WJC, до якої підключилися і чиновники Державного Департаменту США, американські дипломати у Швейцарії, Іспанії та представники інших міжнародних організацій (Penkower, 1988: 127-129).

Важливою подією міжнародного масштабу, підсумки якої сприяли утворенню WRB, стала Бермудська конференція (квітень 1943 р.) між США та Великою Британією. I, хоча, в цілому, вона була невдалою (представниками США та Великої Британії були не ключові дипломати; конференція швидше за все мала заспокоїти західне суспільство у тому, що допомога цивільному населенню Свропи продовжує поступати), проте вона поставила ключове питання - долі військових біженців. Зазначимо, що основним очікуванням від конференції було надання всім євреям, що перебували під нацистською окупацією, статусу військовополонених (Gorny, 2012: 160). Але на практиці цього не відбулося. Тож американське єврейство ініціювало «власну» конференцію - Надзвичайну конференцію щодо порятунку євреїв Свропи. Фактично, це була зустріч групи Пітера Бергсона ${ }^{8}$ у Нью-Йорку в липні 1943 р. Напередодні був виданий меморандум «Надзвичайної конференції щодо порятунку євреїв Свропи: проект програми та ії̈ цілі», що не містив жодних посилань на американську організацію, лише «пропозицію урядам про створення Агенції Об`єднаних Націй для порятунку мільйонів євреїв, що залишалися живими», дотичного тому, що було запропоновано ведучими єврейськими групами за рік до цього. В основі iї вже були «звичні» питання: «пряма допомога у наданні їжі та одягу євреям Європи», «масовий вихід євреїв з Свропи», ін. (Rubinstein, 1997: 107-109). Результатом Надзвичайної конференції стало створення комітету із відповідною назвою, який очолив П. Бергсон. У свою чергу, цей комітет, використовуючи усі доступні йому засоби (передусім, факт дружби Бергсона із багатьма представниками влади США), намагався чинити тиск у питанні створення нової агенції з надання допомоги та порятунку євреїв Європи, якою став WRB (Rubinstein, 1997: 110). Зрештою, це вдалося. Вже 13 січня 1944 р. активна група американських високопосадовців - Генрі Моргентау, Джон Пелл та ін. - направили президенту Рузвельту «Звіт мовчазної згоди уряду Рузвельта у вбив-

\footnotetext{
${ }^{7}$ Насправді, телеграма Г. Рігнера була відправлена ще у серпні 1942 р. Проте уряди західних країн, а також представники американського єврейства (наприклад, той же С. Вайс) зустріли цю інформацію 3 недовірою. Проте, коли звістки про знищення євреїв вже почали поширюватися по всім каналам дипломатичного зв’язку, почала надходити певна реакція урядовців США.

${ }^{8}$ Пітер Бергсон (псевдонім Гілеля Кука) - активіст ревізіоністського сіонізму, політик, член Іргуну (сіоністської напіввійськової організації, яка діяла у Палестині впродовж 1930-х - 1940-х рр.).
} 
стві євреїв». Цей документ, де-факто, став останньою крапкою у прийнятті рішень про створенні WRB (Erbelding, 2018: 12-15), який було засновано указом Президента США Ф. Д. Рузвельта 22 січня 1944 р. задля допомоги беззахисним біженцям (зокрема, євреям) «як інтегральної частини глобальної війни проти нацистів». Указ містив наступне: «Політикою цього уряду є прийняття усіх заходів із порятунку жертв ворожої агресії, які знаходяться у невідкладній небезпеці смерті та надання таким жертвам всієї необхідної допомоги та порятунок відповідно до успішного проведення війни» (F. D. Roosevelt Library. Records of the WRB. Folder 34. Vol. I: 1-3). Цей указ забезпечив Комісію усіма повноваженнями, необхідними для проведення ії діяльності.

Про важливий характер агенції свідчив ії склад: Державний секретар, Секретар Казначейства, Секретар по справам війни, вищі офіцери Кабінету - всі ці особи були напряму відповідальні перед Президентом США (F. D. Roosevelt Library. Records of the WRB. Folder 34. Vol. I: 1). Основними функціями WRB були визначені: «розвиток планів та програм інаугурації ефективних заходів щодо порятунку, транспортування, підтримки й допомоги жертвам ворожих репресій; створення тимчасових притулків для таких біженців» (F. D. Roosevelt Library. Records of the WRB. Folder 34. Vol. I: 2). Перед Комісією були поставлені завдання залучати до співробітництва 3 питань допомоги та порятунку військовим біженцям зарубіжні уряди та міжнародні організації (F. D. Roosevelt Library. Records of the WRB. Folder 34. Vol. I: 13).

Особливу важливість представляє положення щодо представництв WRB за кордоном: «...певні кроки зроблені для створення Спеціальних представників Комісії у стратегічних місцях: Туреччині, Швейцарії, Швеції, Португалії, Великій Британії, Італії та Північній Африці. Ці представники отримали дипломатичний статус та були уповноважені як Спеціальні аташе по справах військових біженців із поважною місією Державного Департаменту США...» (History of the WRB with Selected Documents. Vol. I: 3).

Основні кошти надходили від Держдепу та інституцій, які фінансувалися або були підпорядковані США; проте чимало грошей отримувала WRB через різні приватні організації (донорів), які розподіляв через різні установи, державні та недержавні.

Для кращого розуміння діяльності WRB слід відмітити механізм іiі взаємодії з різними установами, благодійними агенціями.

Так, відразу після створення, представники WRB запросили Генрі Емерсона, директора IGCR 9 , до Вашингтону на консультацію. Впродовж цього візиту була досягнута угода щодо робочих стосунків між двома установами. Крім того, WRB отримала \$ 2 млн. від Президентського надзвичайного фонду за плату. Комісія витратила більшість цих коштів на операції з порятунку біженців у Франції, Угорщині, Румунії, використовуючи у якості своїх агентів представників іншої, єврейської, організації - JDC (History of the WRB with Selected Documents. Vol. III. Memorandum from the Director of the Intergovernmental Committee dated April 14, 1944: 1289-1292; Memorandum to the Director of the Intergovernmental Committee dated April 17, 1944: 1293).

Представництва ICRC були також запрошені до співпраці: вони отримували від WRB, головним чином, гуманітарну допомогу (речі, ліки), яку поширювали на ворожій території, а також слугували каналом комунікації з нацистськими чиновниками (History of the WRB with Selected Documents. Vol. III. Cable № 279 to Bern dated January 27, 1944: 1185).

\footnotetext{
${ }^{9}$ Міжурядовий комітет по справах біженців (Intergovernmental Committee on Refugees, IGCR) - організація, організована у Лондоні у серпні 1938 р. у результаті Евіанської конференції 1938 р.
} 
Приблизно \$ 20 млн. 3 приватних фондів було ліцензовано Управлінням казначейства США для передачі за кордон приватним організаціям з надання допомоги, діяльність яких координувалася представниками WRB. Понад \$ 15 млн. було надано JDC; понад \$ 1 млн. від «Vaad Haatzala» ${ }^{10}$ та понад \$ 300 тис. - для WJC (F. D. Roosevelt Library. Records of the WRB. Folder 34. Vol. I: 6).

Програми, заплановані та розроблені WRB, реалізовувались одночасно в трьох напрямках. По-перше, це були заходи, спрямовані на порятунок біженців від переслідувань та загибелі шляхом їхньої евакуації з території ворога у безпечний притулок. По-друге, цільові психологічні заходи, які мали впливати на гітлерівські сили, особливо їх підлеглих і супутників, не співпрацювати в нацистській політиці переслідування та знищення меншин та звірства проти євреїв та інших цивільних осіб. По-третє, були засоби, за допомогою яких WRB намагалася отримати кращі умови для депортованих і затриманих у нацистських концентраційних таборах та підтримувати їхнє життя до остаточного порятунку чи звільнення (F. D. Roosevelt Library. Records of the WRB. Folder 34. Vol. I: 8).

Фінансування рятувальних операцій за рахунок коштів, що переміщувались 3 держав-членів, стало можливим завдяки значній зміні політики Казначейства та Держдепу безпосередньо перед заснуванням WRB. Було вирішено, що уряд Сполучених Штатів дозволить встановленим приватним установам переказувати кошти від США їхнім представникам у нейтральних країнах для фінансування рятування переслідуваних народів, які знаходилися під нацистським контролем. Для покриття всіх таких переказів була розроблена основна казначейська ліцензія Департаменту торгівлі. Ця ліцензія дозволила забезпечити необхідне спілкування, зокрема, з представниками міжнародних організацій на території ворога та фінансування рятувальних операцій за визначеними методиками, призначеними для того, щоб не принести ніякої фінансової вигоди ворогу. Після створення WRB всі запити на отримання ліцензій цього типу були передані через неї і видавалися лише за їі рекомендаціями, забезпечивши координацію всіх програм порятунку (F. D. Roosevelt Library. Records of the WRB. Folder 34. Vol. I: 8-9).

Охарактеризуємо основні операції з порятунку єврейського населення, проведених WRB за участі iіi представництв у тій чи іншій країні Європи. Протягом діяльності Комісії (1944 - 1945) було здійснено декілька десятків операцій по всій Свропі, багато з яких були направлені саме на порятунок євреїв. Проте, зауважимо, що багато рятувальних місій мали на меті надати порятунок загалом постраждалому цивільному населенню Свропи. I в таких випадках важко виокремити «єврейську» складову. Тож спробуємо показати ті операції, які мали безпосереднє відношення до європейського єврейства.

Відразу після свого створення, однією з перших країн, де Комісія розпочала свою діяльність, стала Туреччина. Спеціальним представником WRB було обрано Айру Хipшмана (певний час його заступав Герберт Кацкі), який разом із американським послом Лоуренсом Штейнхардтом проводили усі перемовини з турецькою владою стосовно біженців з Свропи (F. D. Roosevelt Library. Records of the WRB. Folder 34. Vol. I. Cable № 120 to Ankara dated February 12, 1944: 456). Попередня система евакуації біженців до цієї країни (а в подальшому - до Палестини) була недостатньо ефективною: для евакуації подавалися відбіркові списки осіб з Болгарії, Румунії та Угорщини, які мог-

${ }^{10}$ «Ваад Хаатзала» (Vaad Haatzala) - єврейська добровільна агенція, заснована Союзом ортодоксальних рабинів у США та Канаді, діяльність якої була зосереджена навколо перебудови єврейського життя серед інтернованих осіб. 
ли отримати транзитну візу для в’їзду до Туреччини, та встановлювалася квота - до 9 осіб на тиждень. Тож відразу після свого призначення, А. Хіршман разом із представниками інших міжнародних агенцій (JDC, ICRC, «Vaad Haatzala») та дипломатичними працівниками розпочали перемовини щодо організації евакуації цивільного населення.

Ще на початку діяльності Комісії спеціальна ліцензія була надана JDC від Департаменту Казначейства, яка дозволяла контактувати з особами на ворожій території, проводити необхідні фінансові транзакції, що мали відношення до порятунку осіб з ворожої території. Переказ коштів на суму \$ 50 тис. було підтверджено для представника JDC в Туреччині та використано для транспортування біженців з Туреччини до Палестини. Інші перекази (загалом, на \$ 641 353) були зроблені JDC до Палестини як відшкодування JА в Срусалимі за кошти, витрачені на евакуацію біженців з Балкан до Палестини (F. D. Roosevelt Library. Records of the WRB. Folder 34. Vol. II. Cable № 532 to Ankara dated June 17, 1944: 547-548). Зазначимо, що це були не одиничні приклади взаємодії різних установ у плані фінансової допомоги єврейському населенню Європи.

Евакуація болгарських та румунських євреїв до Палестини забрала багато часу через постійні перемовини дипломатів, представників міжнародних організацій щодо транспортування (закупка судна, яке могло б якнайбільше перевезти євреїв до Палестини, ін.) (Ofer, 1990: 267-280). Урешті-решт, ці питання були вирішені більш-менш у позитивному, для єврейських біженців, ключі. Загалом, згідно даним щодо операцій 3 порятунку до та через Туреччину (наприкінці 1944 р.), 6527 біженців мали змогу перетнути Туреччину на шляху до Палестини (F. D. Roosevelt Library. Records of the WRB. Folder 34. Vol. II. Dispatch № 808 from Ankara dated October 4, 1944: 756-758). Більшість 3 цих біженців були з Румунії, але також значна кількість польського, словацького, русинського, угорського походження, яким вдалося переїхати до Румунії (F. D. Roosevelt Library. Records of the WRB. Folder 5. Vol. III. Cable № 130 from Ankara dated January 25, 1945: 44).

Одним із центрів діяльності WRB в Свропі стала Швейцุарія. Вибір цієї країни, на думку лідерів WRB, пояснювався 4(!) факторами: географічним: нейтральна країна у центрі ворожої та окупованих ворогом територій; політичним: потужний захист інтересів багатьох воюючих урядів; традиційним: Швейцарія грала міжнародну гуманітарну роль, продовжуючи надавати притулок багатьом біженцям (політичним чи етнічним), тож, очікувалось, що вона буде підтримувати свій інтерес до долі жертв нацистських переслідувань й репресій; фінансовим: країна представляла собою найбільш практичний канал для великих грошових сум, необхідних для рятувальних операцій (History of the WRB with Selected Documents. Vol. I: 43).

Зазначимо також, що велике значення мало те, що у Швейцарії була розташована штаб-квартира ICRC, який мав дуже точні та повні дані стосовно біженців по всій Європі, використання яких було запорукою отримання біженцями допомоги від міжнародних установ (у першу чергу, від WRB).

Враховуючи ці моменти, не виглядає дивним обрання спеціальним представником WRB в Швейцарію Розуелла Макклелланда - людини, яка мала значний досвід роботи в якості волонтера (зокрема, в AFSC) та, відповідно, вже мала контакти з багатьма міжнародними гуманітарними організаціями (Bauer, 1987: 404-408).

Зазначимо, що істотною проблемою для швейцарської влади було розуміння терміну «політичні біженці». У лютому 1944 р. від посла Гаррісона у Берні було отримано попередній звіт щодо ситуації з біженцями у Швейцарії та прагнення швейцарської федераль- 
ної влади допомогти у вирішенні проблеми. Понад 70 тис. біженців були вже вміщені у Швейцарії, а також було підраховано, що щодня прибували від 90 до 100 осіб (History of the WRB with Selected Documents. Vol. II. Cable № 941 from Bern dated February 15, 1944: 531-532). Вже 4 березня 1944 р. посол Гаррісон передав до WRB звіт від швейцарського уряду щодо проблем із біженцями у цій країні, що відображав політику Швейцарії щодо політичних біженців (точніше, їх певних категорій), які могли бути прийняті та розміщені у цій країні: майбутні матері; літні особи разом з їхніми дружинами / чоловіками; немовля та юнаки; особи, які мали близьких родичів у Швейцарії; жінки, які втратили швейцарську національність через шлюб; хворі. Проте вже у наступних звітах категорії осіб, яким дозволявся в 'їзд до країни, зменшилися до трьох: люди похилого віку, жінки з неповнолітніми дітьми, особи, які мали родичів у Швейцарії (History of the WRB with Selected Documents. Vol. II. Cable № 1304 from Bern dated March 4, 1944: 533-535).

Продовжуючи вирішувати дану проблему, Л. Гаррісон звернувся до МЗС Швейцаpiï із пропозицією розглядати в якості «політичних біженців» наступні категорії осіб: євреї без громадянства; єврейські громадяни Німеччини та іiі сателлітів; громадяни держав Об'єднаних Націй, на той момент окупованих німцями (History of the WRB with Selected Documents. Vol. II. Cable № 983 to Bern dated March 24, 1944: 536-537).

Упродовж дискусій між Виконавчим директором WRB та швейцарським послом у Вашингтоні, посол США Гаррісон та представник WRB Маклелланд були запрошені ініціювати неформальну дискусію з проблеми біженців з МЗС Швейцарії; було підкреслено внесок Швейцарії (вже зроблений та який мав бути зроблений у майбутньому) у вирішенні проблеми. Було зазначено, що керівники WRB будуть дуже вдячні за отримання від уряду Швейцарії, неформально та конфіденційно, будь-яких пропозицій майбутніх спільних дій у вирішенні проблем (F. D. Roosevelt Library. Records of the WRB. Folder 5. Vol. III. Cable № 2221 to Bern dated June 30, 1944: 467-468; Cable № 8272 from Bern dated December 21, 1944: 643-645).

Численні звіти, направлені Макклелландом у листопаді 1944 - червні 1945 pp. показують, яка кількість наданих WRB коштів була використана різними єврейськими та неєврейськими організаціями. Ці кошти були реалізовані на таку допомогу: заходи тимчасової підтримки; виготовлення фальшивих документів; транспортування; інші кошти, що забезпечували переховування та різні операції для перетину кордонів (F. D. Roosevelt Library. Records of the WRB. Box 2, American Jewish Joint Distribution Committee / Miscellaneous. Folder 2: 72).

Прикладом ефективної роботи з порятунку єврейського населення Свропи швейцарським офісом WRB (за підтримки «Ге-Халуца» ${ }^{11}$ ) була проведена операція у Польщі, Угорщині та балканських країнах. Так, WRB було виділено фінансові кошти на організацію втечі 2000 осіб до Румунії, 250 - до Словаччини, 500 - до Північної Югославії. Певні кошти допомогли у підтримці та захисті єврейської молоді у переховуванні в Будапешті, Празі, Братиславі й Берліні, а також у втечі невеличкої групи з Берліну до Швейцарії у березні 1945 p. (History of the WRB with Selected Documents. Vol. I: 54-55).

Однією з найуспішніших операцій стала евакуація єврейських дітей з Франції. Ще на початку 1944 p. WRB отримав велику кількість звітів із приватних ресурсів щодо 8-10 тис. єврейських дітей, залишених батьками через депортацію та інші причини. 3 метою реалізації цієї програми WRB тісно співпрацював з JDC. Зусиллями організацій, урядів США та Швейцарії, вже у березні 1944 р. було надано підтвер-

${ }^{11}$ «Ге-Халуц» - єврейський молодіжний рух, який готував молодь до життя у сільськогосподарських поселеннях у Палестині. 
дження на видачу імміграційних віз США 4 тис. особам впродовж першої половини 1944 р. Проте через певні труднощі (жваве обговорення викликало питання: чи були сиротами залишені діти або все ж таки вони мали родичів), процес еміграції істотно уповільнився. Активне сприяння у питанні евакуації дітей відіграли уряди південноамериканських країн, Канади та інших держав, які зменшили обмеження на в’їзд до своїх країн (F. D. Roosevelt Library. Records of the WRB. Folder 3. Vol. II. Memorandum from the United States Embassy in Ottawa dated February 15, 1944: 27-29; Cable № 1215 to Rio de Janeiro dated April 14, 1944: 61).

У серпні 1944 р., через початок депортацій угорських євреїв до таборів смерті, американські консули у Швейцарії отримали дозвіл на видачу віз дітям, що прибували 3 Угорщини (близько 5 тис.). Перед цим швейцарський уряд проінформував свого посла у Будапешті про те, що Швейцарія підготує тимчасовий притулок 8 тис. особам, які мають сертифікати Палестини, але вони поки не можуть туди в’їхати.

В цей же час було розпочато операції з евакуації євреїв 3 концентраційних таборів Берген-Бельзен, Терезієнштадт до Швейцарії, а невдовзі (завдяки зусиллям представників WRB), - до Палестини (History of the WRB with Selected Documents. Vol. II. Cable № 913 from Bern dated February 9, 1945: 604-605).

На початку 1945 р. Макклелланд звітував про те, що німецький уряд повідомив ICRC про згоду на виїзд з Німеччини певних категорій затриманих осіб, непридатних для праці (в основному, літніх людей - понад 65 років, незалежно від статі, а також жінок та дітей). Звіт продемонстрував принципову згоду Німеччини «репатріювати» певні категорії безробітного цивільного населення. WRB запропонувала, щоб вантажівки, доступні для поставок посилок військовополоненим, були використані на своєму зворотному шляху до Швейцарії для евакуації таких затриманих осіб. У цілому, було погоджено про евакуацію затриманих осіб французької та бельгійської національності, i лише шляхом обміну на подібні німецькі групи, утримувані Бельгією та Францією (F. D. Roosevelt Library. Records of the WRB. Folder 34. Vol. I. Cable № 1092 to Bern dated March 16, 1945: 51-53). Зауважимо, що у документі не було відзначено, чи були затримані особи євреями або не євреями, що ускладнює розуміння того, чи можна вважати дану операцію власне «єврейською».

Одним із центрів для передачі коштів, необхідних для допомоги та порятунку, місцем концентрації евакуйованих осіб з Норвегії, Данії, Фінляндії, Польщі та країн Балтії, стала Швеція. Представником WRB було призначено Айвера Олсена, який отримав \$ 200 тис. на рятувальні операції, які він здійснював (F. D. Roosevelt Library. Records of the WRB. Folder 61 Administrative Matters - Personnel - Olsen Iver C. Letter to John W. Pehle, October 12, 1944: 6-15).

Однією з найбільш успішних проектів у Швеції була американська програма порятунку та допомоги у Норвегії. У червні - грудні 1944 р. понад 6 тис. осіб з цієї країни були евакуйовані до Швеції (History of the WRB with Selected Documents. Vol. II. Cables № 2652, 3199, 3864, 4348, 4620, 463 from Stockholm dated July, 1944 - February 1945: 625-629, 632). 3 січня 1945 р. стало можливим задіяти комфортабельні кораблі для організованих евакуацій, і впродовж перших 4 місяців 1945 р. приблизно 4500 біженців були перевезені зі Швеції до Норвегіï (History of the WRB with Selected Documents. Vol. II. Reports from Lars Evensen to Representative Olsen dated May 25 and June 8, 1945: 636-637) (як можна здогадатися, у цю кількість входили не лише норвезькі євреї).

У цей же час урядом Швеції була ініційована одна із найуспішніших програм 3 надання допомоги єврейському населенню Угорщини за участі WRB, JDC, а також 
шведських дипломатів. Для іiї реалізації було обрано Рауля Валленберга, шведського бізнесмена. Коли ситуація з євреями Угорщини істотно погіршилася, JDC отримав ліцензію на відправку \$ 100 тис. до Швеції, і ці гроші були надані представником WRB А. Олсеном Р. Валленбергу для операцій з допомоги та порятунку в Угорщині. Для цього Валленберг закуповував низку будинків у Будапешті, які позначалися як «безпечні будинки» під захистом швецького уряду. Так, згідно документу: «... JDC отримав ліцензію на відправку \$ 100 тис. до Швеції, і ці кошти стали доступними представником Комісії Олсеном для Валленберга для здійснення операцій із порятунку та допомоги в Угорщині... Програма видачі шведських захисних паспортів, переховування євреїв у шведських захисних будинках призвели до того, що приблизно 20 тис. євреїв перебували під шведським захистом...» (F. D. Roosevelt Library. Henry Morgenthau Jr. Papers. Bох 169, Joint Distribution Committee, 1933 - 1944. Folder 1: 159). У січні 1945 р. Валленберг зник. Вочевидь, він був викрадений співробітниками радянського СМЕРШу та перевезений до в'язниці на Луб'янці, де помер у 1947 р.

Шведський офіс WRB продовжував свою діяльність і після зникнення Валленберга. Були проведені рятувальні операції з евакуації євреїв з Румунії, Болгарії до Туреччини; евакуйовані данські та норвезькі євреї й перевезені до Швеції; звільнені жінки (в тому числі, єврейки) з концентраційного табору Равенсбрюк та організовано їхню евакуацію до Швейцарії (F. D. Roosevelt Library. Records of the WRB. Folder 34. Vol. III. Dispatch №3223 from Stockholm dated April 24, 1944: 235).

Ще однією країною, звідки WRB переправив євреїв із Європи у безпечні регіони, стала Італія, переваги якої були зумовлені ії̈ географічним розташуванням_та можливістю організувати евакуацію цивільного населення через середземноморські порти. Спеціальним представником WRB було призначено Леонарда Акермана (спочатку він був представником Комісії у Північній Африці), який мав відповідати за питання з біженцями в Італії, Корсиці, Сардинії, Югославії та інших прилеглих територій (в тому числі, Північну Африку) (F. D. Roosevelt Library. Records of the WRB. Folder 34. Vol. II. Cable № 612 to Algiers dated February 26, 1944; Cable № 1086 to Algiers dated April 13, 1944: 124; 133). Однією з перших операцій, проведених WRB в регіоні, стала допомога та евакуація біженців 3 о. Раб (біля узбережжя Хорватії) до території, контрольованої югославськими партизанами (History of the WRB with Selected Documents. Vol. I: 99). Цікаво, що згідно отриманим JDC звітам, югославські партизани також допомагали в отриманні певних продовольчих пакунків євреям у контрольованій нацистами частині Хорватії (Там само). На той момент значною проблемою було перенаселення певних пунктів для біженців, зокрема на півдні Італії, куди прибували біженці з Югославії. За погодженням з низкою організацій i, передусім, з президентом Ф. Рузвельтом, було прийнято рішення, що «в 'їзд біженців до Італії заборонено за жодних обставин» (F. D. Roosevelt Library. Records of the WRB. Folder 34. Vol. II. Cables № 1373 and 1795 to Algiers dated May 6 and June 6, 1944: 147; 149). Проте остаточно це питання не вдалося вирішити, перемовини продовжувалися і в подальшому.

У зв'язку із завершенням Другої світової війни необхідність у WRB як агенції з надання порятунку постраждалому цивільному населенню зникає. За наказом президента США Г. Трумена № 9614 від 14 вересня 1945 р., діяльність Комісії була припинена, «всі справи мали бути завершені не пізніше 30 червня 1946 р.» (H. S. Truman Library. Executive Order by President Harry S. Truman, № 9614, September 14, 1945. Available at: https://trumanlibrary.org/executiveorders/index.php?pid=379). 
Висновки. WRB був першою урядовою агенцією, яка надавала допомогу та порятунок єврейському населенню в роки Голокосту. Завдяки особам-засновникам (Д. Пеллу, Г. Моргентау та ін.), представникам в інших країнах (Р. Макклелланду, Р. Валленбергу, А. Олсену, А. Хіршману), Комісії вдалося наладити ефективну взаємодію 3 різними установами (приватними та державними, єврейськими та міжнародними) по всьому світу. Серед країн, з якими співпрацювала WRB - JDC, ICRC, WJC, JA, «Vaad Haatzala», ін. Основні види діяльності WRB:

- видача спеціальних ліцензій Комісії на гуманітарну діяльність інших установ;

- передача коштів представникам WRB або посередникам - лідерам інших агенцій, які отримали ліцензії (дозвіл) оперувати коштами WRB (а відповідно, уряду США);

- надання продуктів харчування, одягу постраждалим цивільним особам (у тому числі, євреям);

- видача віз (передусім - американських) для подальшого виїзду євреїв 3 «транзитного» пункту (Швейцарії, Іспанії, Португалії, Туреччини) до США, Канади, країн Південної Америки, Палестини;

- власне еміграція (супроводження, транспортування) до безпечних місць.

Враховуючи початок діяльності WRB лише на останньому етапі війни (з 1944 р.), коли масове винищення єврейського населення Європи майже було завершено, оцінювати ступінь ефективності WRB (порівняно з іншими організаціями, які розпочали свою діяльність напередодні Голокосту) $є$ невірним та некоректним. Тому в даному випадку звернемося до фінального звіту з діяльності WRB, де зазначено наступне: «Коли війна в Європі нарешті завершилася, специфічне завдання, покладене на WRB було виконано. Досягнення Комісії не можуть бути оцінені завдяки статистичним даним. Проте, результатом порятунку численними міжнародними організаціями були сотні тисяч людей, в тому числі десятки тисяч врятованих завдяки діяльності саме WRB». Деякі західні дослідники оперують даними про порятунок «приблизно 200 тис. євреїв та мінімум 20 тис. неєвреїв (Wyman, 2007: 11).

Зауважимо, що у втіленні кожної операції WRB вельми важливу роль відіграли особистості - лідери / представники Комісії в певних країнах Європи. Саме від їхніх здібностей залежало більшість організаційних моментів в операціях. Такими були: А. Хіршман у Туреччині, Р. Макклелланд у Швейцарії, І. Олсен та Р. Валленберг у Швеції тощо.

Слід підкреслити, що багато питань 3 діяльності WRB залишається ще недостатньо вивченими. До них, зокрема, належить визначення загальної кількості врятованих осіб (єврейське та неєврейське населення), необхідне для розуміння ролі, яку зіграла Комісія у порятунку цивільного населення Європи. 3 огляду на те, що «єврейський» аспект фігурував не завжди в документах WRB, визначення кількості врятованого саме єврейського населення $є$ практично неможливим. Окрему проблему становить залучення документів з європейських архівів, які поки що недостатньо використані дослідниками при висвітленні діяльності власне американських організацій (WRB, JDC тощо). Важливим питанням залишається використання мемуарних джерел лідерів WRB, інших установ, для уявлення про порятунок європейського єврейства, i, зокрема, діяльність міжнародних організацій. 


\section{BIBLIOGRAPHY}

Bauer, 1987 - Bauer Y. American Jewry and the Holocaust: The American Jewish Joint Distribution Committee, 1939 - 1945. Detroit: Wayne State University Press, 1987. 574 p. [in English]

Erbelding, 2018 - Erbelding R. Rescue Board: The Untold Story of America's Efforts to Save the Jews of Europe. New York: Doubleday, 2018. 384 p. [in English]

Franklin D. Roosevelt Presidential Library \& Museum. Records of the War Refugee Board, 1944 1945 (далі - F. D. Roosevelt Library. Records of the WRB). [in English]

Gorny, 2012 - Gorny Y. The Jewish Press and the Holocaust, 1939 - 1945: Palestine, Britain, the United States, and the Soviet Union. New York: Cambridge University Press, 2012. 285 p. [in English]

Harry S. Truman Library and Museum administered by the National Archives and Records Administration (далі - H. S. Truman Library). [in English]

History of the WRB, 1946 - History of the War Refugee Board with Selected Documents. Washington, D. C.: War Refugee Board, 1946. Volumes I-III, 1433 p. [in English]

London, 2003 - London L. Whitehall and the Jews, 1933 - 1948: British Immigration Policy, Jewish Refugees and the Holocaust. Cambridge University Press, 2003. 332 p. [in English]

Ofer, 1990 - Ofer D. Escaping the Holocaust: Illegal Immigration to the Land of Israel 1939 1944. New York: Oxford University Press, 1990. [in English]

Penkower, 1988 - Penkower M. The Jews Were Expendable: Free World Diplomacy and the Holocaust. Detroit: Wayne State University Press, 1988. 432 p. [in English]

Rubinstein, 1997 - Rubinstein W.D. The Myth of Rescue: Why the Democracies Could Not Have Saved More Jews From the Nazis. London; New York: Routledge, 1997. [in English]

Wayman, 2007 - Wayman D. The Abandonment of the Jews: America and the Holocaust 1941 1945. The New Press; Complete Numbers Sta edition, 2007. 458 p. [in English]

Стаття надійшла до редакиії 25.10.2018 p. Стаття рекомендована до друку 25.11.2018 p. 